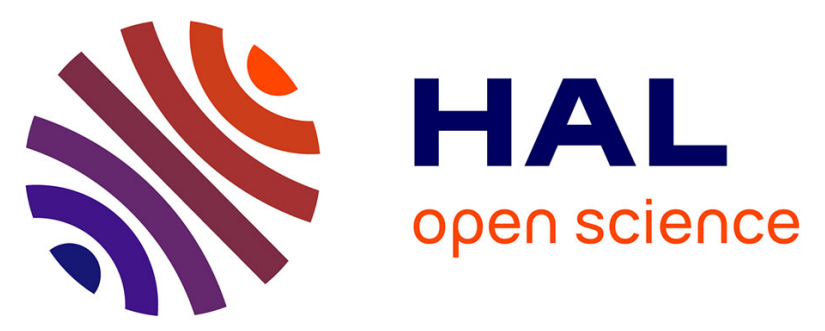

\title{
Molecular characterization of phytoseiid mites in Turkey based on the internal transcribed spacer (ITS) region, with a new record for the country
}

Emre İnak, Sultan Çobanoğlu, Elif Sade, Marie-Stéphane Tixier

\section{- To cite this version:}

Emre İnak, Sultan Çobanoğlu, Elif Sade, Marie-Stéphane Tixier. Molecular characterization of phytoseiid mites in Turkey based on the internal transcribed spacer (ITS) region, with a new record for the country. Experimental and Applied Acarology, 2020, 81 (2), pp.201-213. 10.1007/s10493-02000504-3 . hal-02777305

\section{HAL Id: hal-02777305 \\ https://hal.inrae.fr/hal-02777305}

Submitted on 4 Jun 2020

HAL is a multi-disciplinary open access archive for the deposit and dissemination of scientific research documents, whether they are published or not. The documents may come from teaching and research institutions in France or abroad, or from public or private research centers.
L'archive ouverte pluridisciplinaire HAL, est destinée au dépôt et à la diffusion de documents scientifiques de niveau recherche, publiés ou non, émanant des établissements d'enseignement et de recherche français ou étrangers, des laboratoires publics ou privés.

\section{(ㄷ)(1) $\$$}

Distributed under a Creative Commons Attribution - NonCommerciall 4.0 International 


\title{
Molecular characterization of phytoseiid mites in Turkey based on the internal transcribed spacer (ITS) region, with a new record for the country
}

\author{
Emre İnak $^{1}$ (D) Sultan Çobanoğlu ${ }^{1}$ (D) Elif Sade ${ }^{2}$ D $\cdot$ Marie-Stéphane Tixier $^{3}$ (D)
}

Received: 27 February 2020 / Accepted: 15 May 2020

(c) Springer Nature Switzerland AG 2020

\begin{abstract}
The family Phytoseiidae contains many predatory mite species and some are used in biological control programs worldwide. The identification of phytoseiid mites is based on tiny morphological structures and sometimes species diagnosis is not easy especially for nontaxonomists. DNA-based approaches may offer a fast and accurate diagnosis to overcome these difficulties, nevertheless more DNA sequences are needed to determine intra- and inter-specific variations and to provide accurate decision rules based on genetic distances between the taxa considered. In this study, we provide the molecular characterization of seven phytoseiid species based on the internal transcribed spacer (ITS) region. Several populations of these species collected in Turkey were considered. A phylogenetic tree was also constructed. Finally, we record the presence of Neoseiulus reductus (Wainstein) in Turkey.
\end{abstract}

Keywords Phytoseiidae $\cdot$ Internal transcribed spacer $\cdot$ Euseius finlandicus $\cdot$ Neoseiulus reductus

\section{Introduction}

The family Phytoseiidae includes many predatory mite species, some being commonly used in biological control programs (McMurtry et al. 2013; Tixier 2018). Predatory mites can control pest mites as well as small insects such as whiteflies and thrips (van Lenteren 2012). Phytoseiid mites are reported from all continents except Antarctica (Tixier et al. 2010a; McMurtry et al. 2015) and more than 2500 species have been described so far (Chant and McMurty 2007; Demite et al. 2020).

Emre İnak

einak@ankara.edu.tr

1 Department of Plant Protection, Faculty of Agriculture, Ankara University, Diskapi, 06110 Ankara, Turkey

2 Department of Plant Protection, Institute of Science, Bursa Uludag University, Gorukle Campus, 16059 Bursa, Turkey

3 CBGP, Montpellier SupAgro, INRA, CIRAD, IRD, Univ. Montpellier, Campus International de Baillarguet, CS 30016, 34988 Montferrier-sur-Lez cedex, Montpellier, France 
Morphological identification of phytoseiid mites is based on tiny morphological structures and seta measurements (Chant and McMurtry 2007). The observation of these structures is sometimes difficult. Futhermore, diagnosis decisions are sometimes difficult to take because of lack of knowledge concerning intraspecific variation for continuous characters (e.g., seta length) (Tixier 2012, 2013). As a consequence, a high level of expertise is often required (Döker et al. 2018) and the existence of cryptic species is difficult to assess (Tixier et al. 2006; Kanouh et al. 2010a; Skoracka et al. 2015). Besides, keys for morphological identifications are only available for adult females that prevent the correct identification of other stages (immatures and males) (Okassa et al. 2012). Diagnosis improvement is thus required especially because the basis of success of biological control is the correct identification of the natural enemies (Rosen 1986).

Along with progress in molecular techniques, DNA-based identification methods have been used to overcome morphological diagnosis difficulties (Hebert et al. 2003; Navajas and Fenton 2000; de Mendonça et al. 2011). However, using molecular analysis in phytoseiid mites is not so easy (Jeyaprakash and Hoy 2002) and there are also some critical views to public GenBank database due to misidentification, contamination and nomenclatural errors/updates (Tixier et al. 2011). To overcome this problem, the combination of molecular and morphological approaches (by DNA extraction of single mites and recovering the carcass of mites after DNA extraction) can be used (Jeyaprakash and Hoy 2010; Tixier et al. 2010b). Another key point for molecular identification is to characterise intraand inter-specific variation to propose decision rules (Tixier et al. 2017, 2019). The challenge is thus to obtain more sequences for more species and populations collected in different localities. Only two DNA sequences (ITS) of a species of Phytoseiidae from Turkey are present in GenBank (Kampimodromus ragusai Swirskii \& Amitai; Döker et al. 2018). The objective of this study is to fill this gap, obtaining and analysing the DNA sequences of seven Phytoseiidae species collected in Turkey.

\section{Material and methods}

\section{Mites}

The specimens were collected from various locations of Turkey in 2019 (Fig. 1). They were placed in plastic vials containing 70 and $100 \%$ alcohol for morphological and molecular identification, respectively. Detailed information on collection sites is presented in Table 1. Hoyer's medium was used for the preparation of permanent slides and morphological identification (Zhang 2003). The generic classification of Chant and McMurtry (2007) was used in this paper. The specimen identified as Neoseiulus reductus (Wainstein) was measured, and terminology for seta notation follows that of Lindquist and Evans (1965) as adapted by Rowell et al. (1978) for Phytoseiidae. The permanent slides are deposited at Ankara University, Department of Plant Protection, in case of future verification.

\section{DNA extraction}

Genomic DNA was extracted from individual female mites using Qiagen DNeasy Blood $\&$ Tissue Kits as described by Kanouh et al. (2010b). As the mites were crushed during the DNA extraction process, only samples with more than one mite specimen were herein 


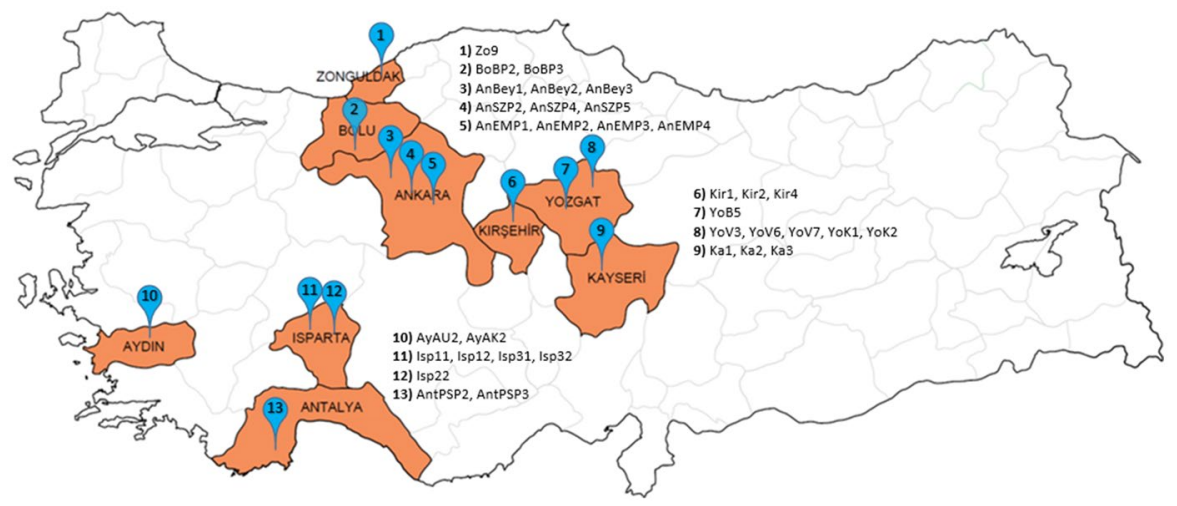

Fig. 1 Map of sampling areas of phytoseiidae species. Numbers indicate the location areas in Table 1

considered (one part being used for morphological identification and the other part for DNA analysis).

\section{DNA fragment considered}

Various molecular markers have been used in mite identification so far (e.g., Navajas and Fenton, 2000; Cruickshank 2002; Dabert 2006; Ros and Breeuwer 2007; dos Santos and Tixier 2016). The internal transcribed spacers (ITS1 and ITS2) of the non-coding region of ribosomal DNA (rDNA) have variable sequences and are among the earliest markers used in Acari (Navajas et al. 1992). They have been reported to usually allow the separation of species (Cruikshank 2002; Tixier et al. 2006). In addition, the ITS region has been reported as a reliable marker to investigate Phytoseiidae phylogeny at species and genus level (Navajas et al. 1999; dos Santos and Tixier 2016).

\section{PCR conditions}

The primers used to amplify the ribosomal internal transcribed spacer (ITS) region including ITS1, 5.8S and ITS2 regions, were as follows: 5'-3' AGAGGAAGTAAAAGTCGT AACAAG and 3'-5' ATATGCTTAAATTCAGGGGG (Navajas et al. 1999). The PCR reaction was performed in a total volume of $30 \mu \mathrm{l}$, containing $5 \mu \mathrm{l}$ of mite DNA, $0.5 \mu \mathrm{l}$ of both forward and reverse primer, $18 \mu \mathrm{l}$ of ultrapure nuclease-free water and $6 \mu \mathrm{l}$ of FIREPol Master Mix (containing reaction buffer, $\mathrm{MgCl}_{2}$ and dNTPs) (Solis Biodyne). DNA amplification was performed with a thermal cycler (BioRad T100) under the following conditions: $4 \mathrm{~min}$ at $94{ }^{\circ} \mathrm{C}, 40$ cycles of $60 \mathrm{~s}$ at $92{ }^{\circ} \mathrm{C}, 60 \mathrm{~s}$ at $50{ }^{\circ} \mathrm{C}$ and $90 \mathrm{~s}$ at $72{ }^{\circ} \mathrm{C}$, followed by a final extension for $5 \mathrm{~min}$ at $72{ }^{\circ} \mathrm{C}$. Electrophoresis was carried out on a $2 \%$ agarose gel in $0.5 \mathrm{X}$ TAE buffer during $35 \mathrm{~min}$ at $100 \mathrm{~V}$.

Cytochrome oxidase I (COI) gene was also amplified only for $N$. reductus specimens. Primers used for COI amplification were as follows: 5'- GGAGGATTTGGAAATTGATTA GTTCC -3' and 5'- TACAGCTCCTATAGATAAAAC -3' (Navajas et al. 1994; Navajas and Boursot 2003). PCR mix and conditions were the same as those mentioned above. 


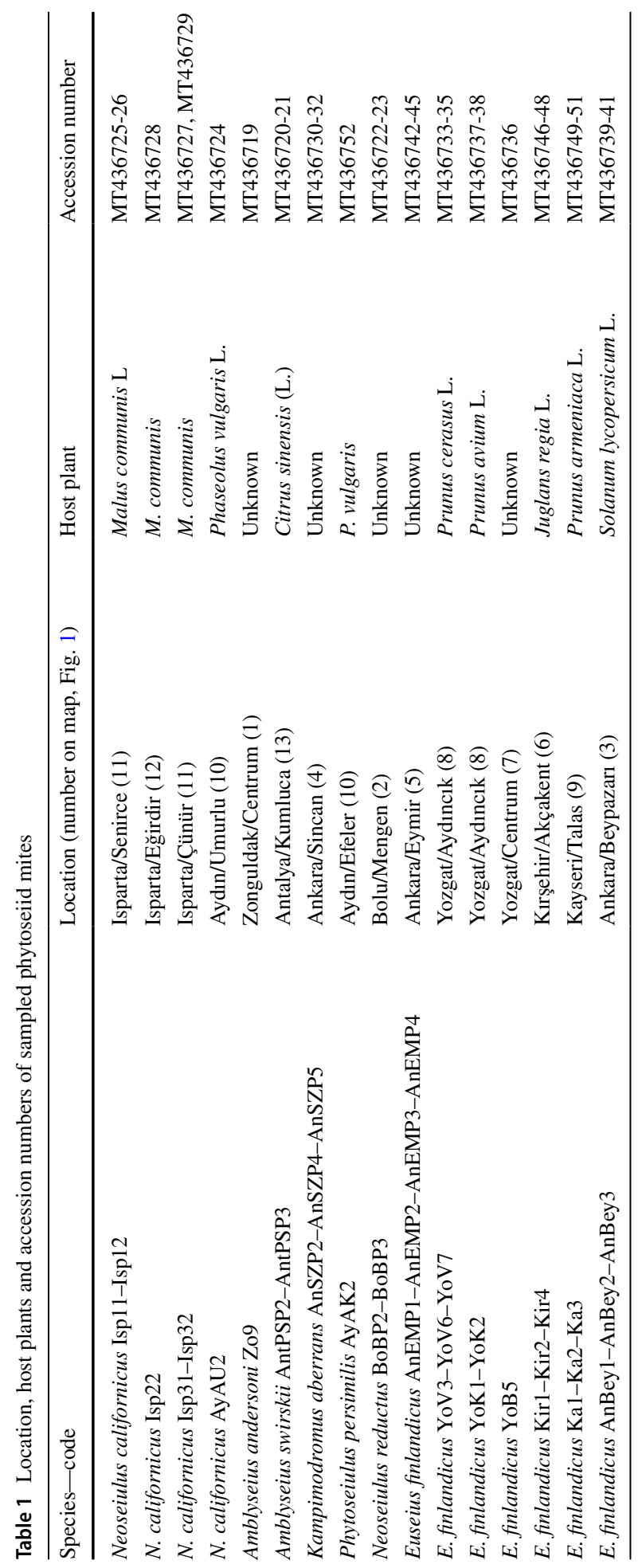




\section{Data and phylogenetic analysis}

The sequences obtained were submitted to the Basic Local Alignment Search Tool (BLAST) in GenBank to check for potential contaminations (other mite families, insects, Human DNA ...). Because of high identity level, all specimens herein considered belong to the family Phytoseiidae. Furthermore, as DNA sequences of the seven species are included in GenBank (and mainly deposited by one of the authors of this article), the blast process allowed to assign without any doubts the present DNA sequences to the correct species name.

To build the phylogenetic tree, the sequences of the species herein obtained and some retrieved in the public GenBank database were also used. The GenBank sequences considered were mostly deposited by M-S Tixier, co-author of this paper. The sequences obtained were cleaned using BioEdit v.7.0.5 (Hall 1999) and all sequences aligned using MAFFT v.7 with default settings (Katoh et al. 2019). A Maximum likelihood (ML) phylogenetic analysis was performed with Molecular Evolutionary Genetics Analysis (MEGA v.7) (Kumar et al. 2016) using the Tamura $3+\mathrm{G}$ model (identified to be the best-fit model in MEGA) (Tamura 1992) with 1,000 bootstraps. The outgroup species is Galendromus occidentalis (Nesbitt) a species of the sub-family Typhlodrominae as all the species herein considered belong to the sub-family Amblyseiinae. Genetic distances between the specimens considered were calculated using the K2Parameter model in MEGA7 (Kumar et al. 2016).

\section{Results and discussion}

\section{Identification and phylogenetic tree}

After alignment, the sequences had a total of 610 nucleotides (including gaps), used for phylogenetic tree construction, and 263 out of the 610 nucleotides were conserved. The aligned sequences had 42.8\% GC-content (57.2\% AT), on average. 34 ITS sequences were obtained: Amblyseius andersoni (Chant) (one specimen), Amblyseius swirskii AthiasHenriot (2 specimens), Euseius finlandicus (Oudemans) (19 specimens), Kampimodromus aberrans (Oudemans) (3 specimens), Neoseiulus californicus (McGregor) (6 specimens), N. reductus (2 specimens) and Phytoseiulus persimilis Athias-Henriot (one specimen). Accession numbers of sequences in GenBank database are included in Table 1.

The phylogenetic tree based on ITS-region is presented in Fig. 2. The phylogenetic tree structure is similar to the ones obtained by Tsolakis et al. (2012) and dos Santos and Tixier (2016, 2018), as almost all sequences are issued from these works. The genus Euseius seems to be paraphyletic as it should include the genus Iphiseius. The genera Neoseiulus and Amblyseius seem to be polyphyletic.

All the specimens of the seven species herein considered are included in clades containing specimens of these species, showing a correct assignation and identification using this molecular marker. The genetic distances between the DNA sequences herein obtained and those of specimens of the same species retrieved from GenBank are very low (0-0.77\%; Table 2$)$. It is interesting to note that some interspecific genetic distances are sometimes very low especially between $N$. fallacis and $N$. californicus (0.9\%) and between P. persimilis and P. macropilis $(0.45 \%)$. These values are lower than the maximal intraspecific distance reported in Tixier et al. (2017). However, these 


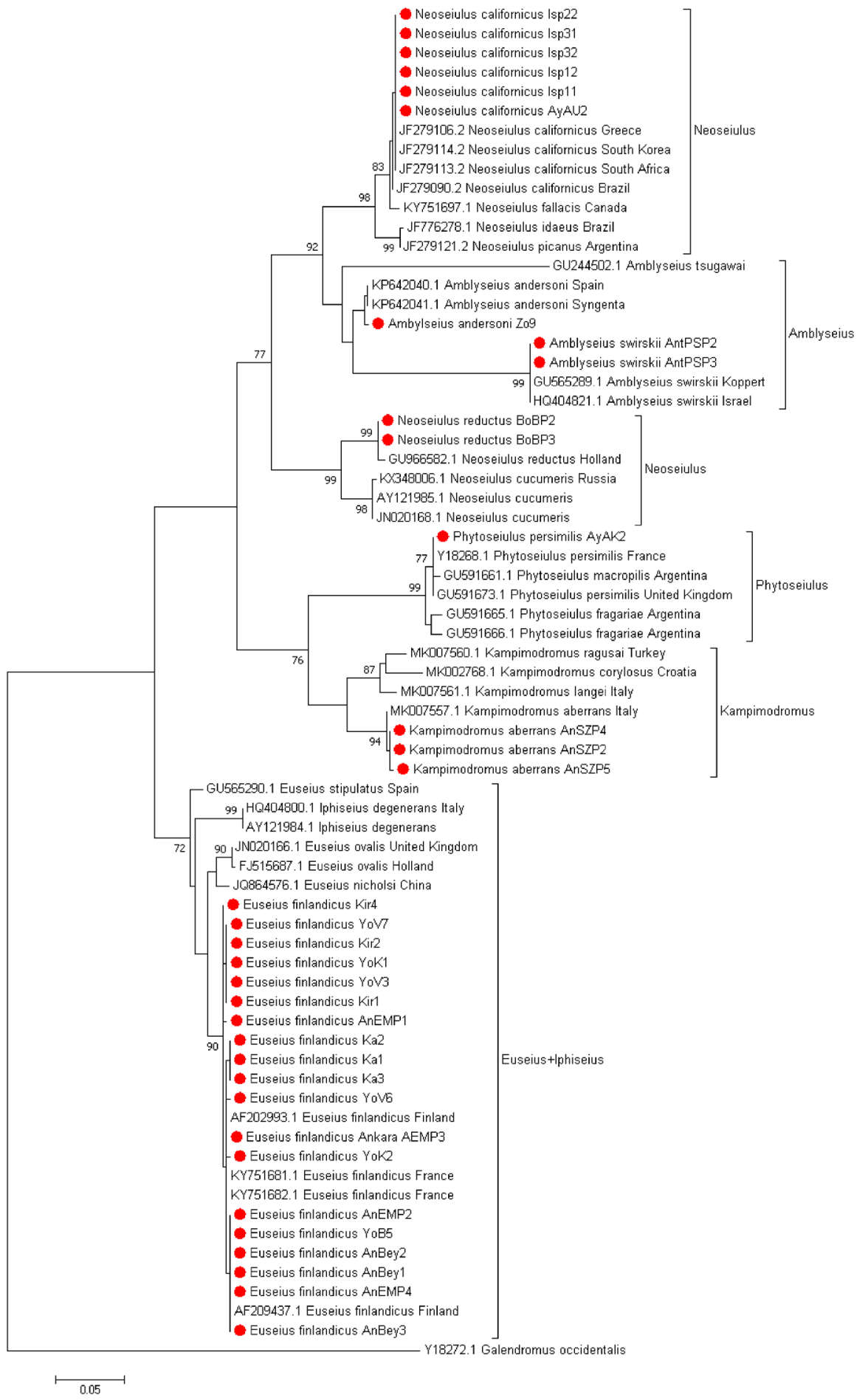

Fig. 2 Phylogenetic tree of phytoseiid mites based on ITS region. Only bootstrap values higher than or equal to $70 \%$ are shown. Sequences of the species obtained in this study are indicated with red dots. (color figure online) 


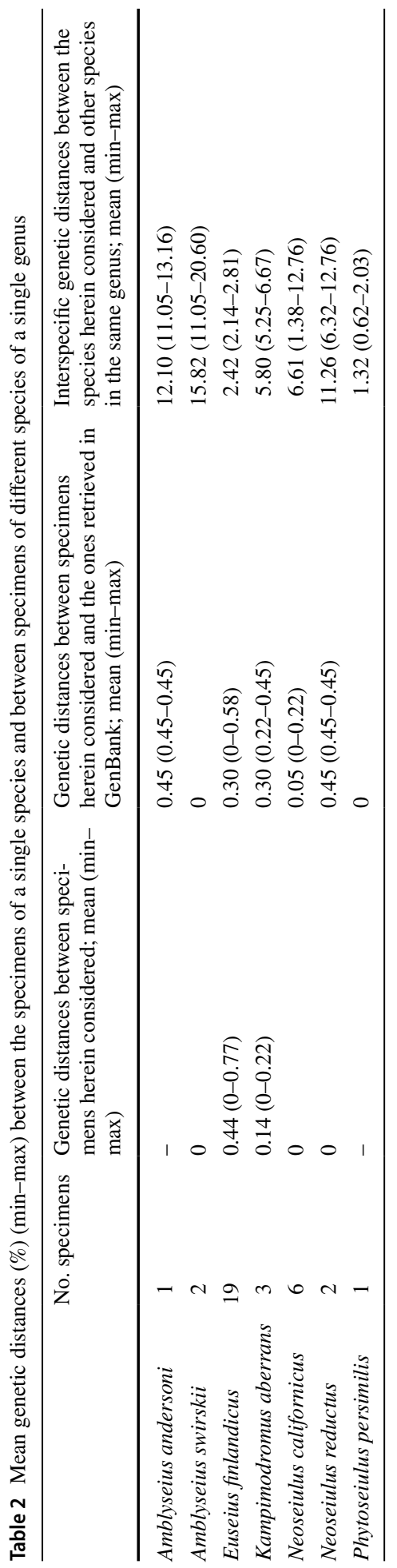


interspecific distances are much higher than the intraspecific distances and no overlap between intra- and interspecific distances is observed, for the four species here mentioned. This may be due to the fact that $N$. californicus and $N$. fallacis on the one hand, and $P$. persimilis and $P$. macropilis on the other hand, are morphologically very close and probably recently divergent species (Kanouh et al. 2010b; Okassa et al. 2010). This result clearly shows the difficulty to use only the marker ITS for molecular identification, and also the difficulty to use only one decision rule for the whole Phytoseiidae family.

Genetic distance between the 19 specimens of E. finlandicus herein considered range between 0 to $0.77 \%$ ( $0.44 \%$ on average). No structuring of these specimens is observed in the phylogenetic tree because of the very small distances. The pairwise distances within the specimens of the populations from Ankara, Yozgat, Kayseri and Kirsehir were 0.16, $0.42,0.00$ and $0.13 \%$, respectively. The average pairwise distances between specimens from Kirsehir and Yozgat populations were the lowest (0.29\%) and those between specimens from Kirsehir and Kayseri were the highest $(0.71 \%)$. No correlation between genetic distance values and geographic distances is observed (Table 3).

\section{First report of Neoseiulus reductus in Turkey}

Neoseiulus reductus has been identified morphologically and molecularly for the first time in Turkey. BLAST results of the two $N$. reductus sequences herein obtained (ITS) showed 99.3 and $99.6 \%$, similar to the reference sequence in GenBank (GU966582 posted by Pham and Van der Linden in 2010), confirming the identity of the two specimens collected. A COI sequence ( 859 bp) has also been deposited in GenBank (accession nr. MT439329). There is no COI sequence in this database, and the Blast analysis only showed that the nearest COI fragment belongs to P. persimilis (accession nr. GQ222414).

In addition, re-description of $N$. reductus is provided based on one female (Fig. 3). All measurements are provided in micrometers. Length and width of dorsal shield is 338 and 142, respectively. Measurements of dorsal setae as follows: $j 118, j 213, j 413, j 513, j 616$, J2 20, J5 10, z2 24, z4 24, z5 13, Z1 19, Z4 41, Z5 65, s4 41, S2 41, S4 34, S5 31, r3 29, and R1 24. Measurements of ventral setae as follows: ST1 10, ST2 10, ST3 10, ST4 10, ST5 11, JV1 15, JV1 16, JV2 18, JV4 15, JV5 40, ZV1 13, ZV2 18, ZV3 10. Length of ventrianal shield is 101; width at level of $Z V 2$ and anus is 77 and 61, respectively. Length of macrosetae on leg IV basitarsus is 36. Although minor morphological differences are present, the lengths of dorsal setae of the Turkish specimens are quite similar with those of Dutch specimens reported by Miedema (1987).

Table 3 Mean genetic distances (\%) (min-max) between the specimens of Euseius finlandicus collected in different locations in Turkey

\begin{tabular}{llllll}
\hline & $\begin{array}{l}\text { No. speci- } \\
\text { mens }\end{array}$ & Ankara & Yozgat & Kırşehir & Kayseri \\
\hline Ankara & 7 & - & & \\
Yozgat & 6 & $0.43(0-0.58)$ & - & - \\
Kırşehir & 3 & $0.49(0.19-0.58)$ & $0.29(0-0.58)$ & - \\
Kayseri & 3 & $0.61(0.58-0.77)$ & $0.68(0.58-0.77)$ & $0.71(0.58-0.77)$ & - \\
\hline
\end{tabular}



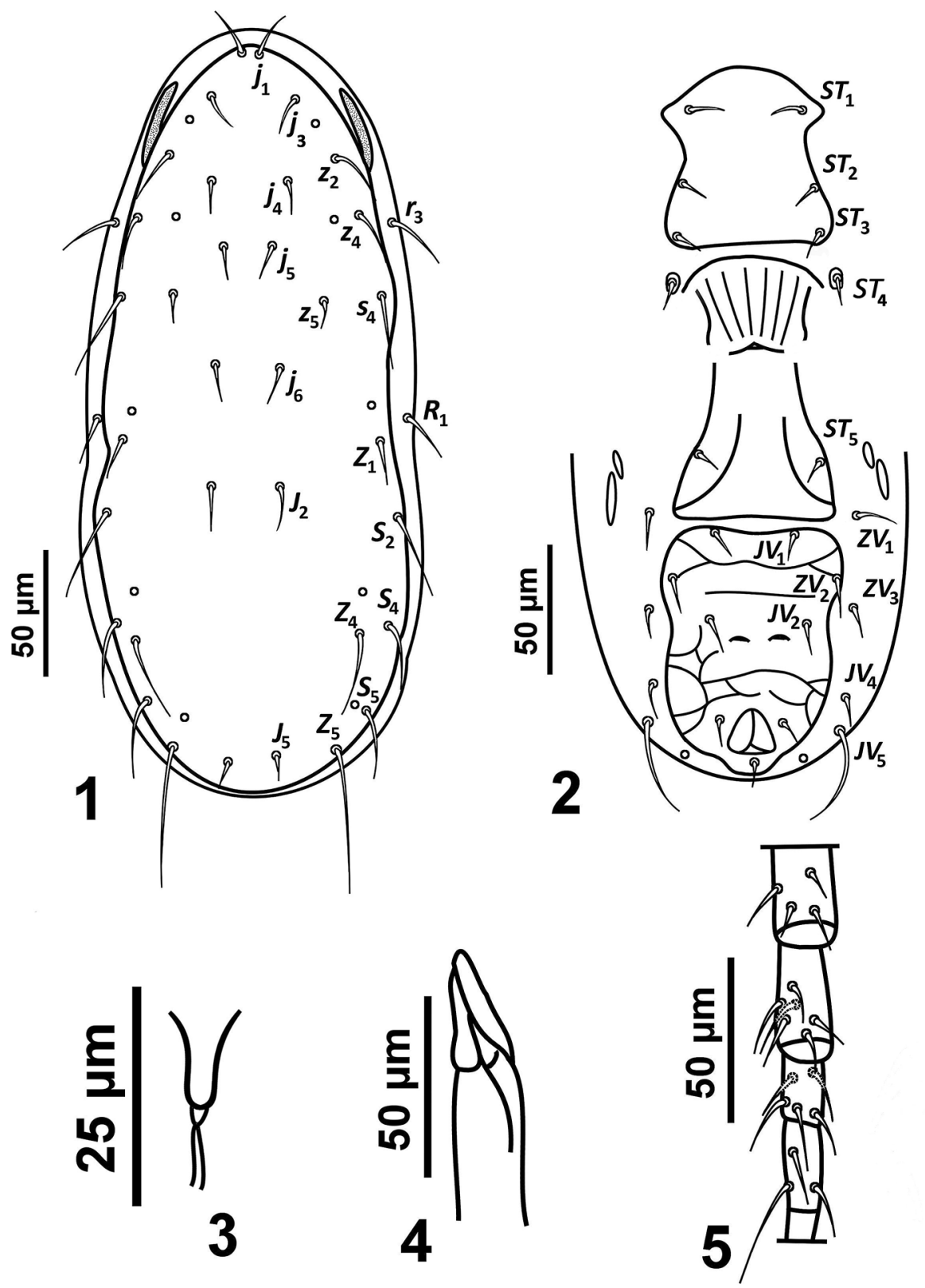

Fig. 3 Female of Neoseiulus reductus: 1. dorsal view, 2. ventral view, 3. spermatheca, 4. chelicera, 5. leg IV

Neoseiulus reductus is morphologically very close to Neoseiulus cucumeris (Oudemans). Ventrianal shield with one pair of distinct eye-shaped pores in N. reductus and punctiform circular pores in $N$. cucumeris. In addition, $J 2$ and $Z l$ are shorter than $S 2$ in $N$. reductus, whereas both setae are about equal length to $S 2$ in $N$. cucumeris (Tuovinen 1993). 


\section{Conclusion}

Accurate identification of phytoseiid mites is essential to design proper pest control programs for agriculture. DNA-based approaches may allow mite identification even by nonexperts under two conditions (i) the existence of a complete reference database, and (ii) clear rules for molecular identification. For this, determination of intra- and interspecific variation is essential to reveal the gaps for molecular identification. The present study correctly assigned the specimens to the species they belong to in the phylogenetic tree. However, we confirm here that ITS sequence is not very variable in phytoseiid mites and intraand interspecific distances are sometimes very close if not overlapping to those of species of different genera (Navajas et al. 1999; dos Santos and Tixier 2016). This clearly shows that a simple and universal decision rule based on distance overlap cannot be applied at family level. More probably, decision rules proposed would have to be different for some genus with more rapid DNA rate evolution (as Phytoseiulus) (Kanouh et al. 2010b; Okassa et al. 2010). Mitochondrial DNA fragments seem more appropriate for separating morphologically close species and the study of intraspecific variation (Okassa et al. 2010; dos Santos and Tixier 2016) because of higher genetic distances within and between species.

In the public GenBank database, only one ITS sequence of $N$. reductus was available so far. Now, we provided the sequences of ITS and COI of two specimens that will help species identification. One important issue is the correct morphological identification. It is worth to consider that different species might co-occur in the same plant samples and it should be prefered to use the non-destructive extraction techniques proposed by Jeyaprakash and Hoy (2010) and Tixier et al. (2010b) to check for the identity of specimens after DNA extraction, especially in case of mismatching. In our study, we did not reveal such problems and only used specimens for DNA analyses, when several specimens were present in a same sample. However, in the future, non-destructive DNA extraction techniques should clearly be favored.

The sequences of ITS regions of seven phytoseiid mite species from Turkey were obtained for the first time. Although about 100 phytoseiid species have been recorded for Turkey (Faraji et al. 2011; Döker et al. 2016), we only have the ITS sequences of eight species (Döker et al. 2018; present study) and only one COI sequence in the GenBank database with a limited number of individuals. Therefore, additional studies on DNA-based identification should be performed to both increase our knowledge on molecular variation within and between species for more precise diagnosis and to elucidate the evolutionary history of phytoseiid mites.

Acknowledgements We would like to thank to Dr. Sibel Yorulmaz Salman (Isparta University of Applied Sciences), Canberk Ay (Ankara University), Naciye Sena Çağatay (Ankara University), Banu Çiçek Tokgöz (Republic of Turkey Ministry of Agriculture and Forestry), Tuba Albayrak (Isparta University of Applied Sciences), Kenan Erdoğan (Ankara University), Esengül Özdemir (Ankara University) and Mehmet Ali Temur (Hacettepe University) for providing plant samples.

\section{References}

Chant DA, McMurtry JA (2007) Illustrated keys and diagnoses for the genera and subgenera of the Phytoseiidae of the world (Acari: Mesostigmata). Indira Publishing House, West Bloomfield, p 220

Cruickshank RH (2002) Molecular markers for the phylogenetics of mites and ticks. Syst Appl Acarol 7(1):3-14. https://doi.org/10.11158/saa.7.1.1 
Dabert M (2006) DNA markers in the phylogenetics of the Acari. Biol Lett 43(2):97-107

de Mendonça RS, Navia D, Diniz IR, Auger P, Navajas M (2011) A critical review on some closely related species of Tetranychus sensu stricto (Acari: Tetranychidae) in the public DNA sequences databases. Exp Appl Acarol 55(1):1-23. https://doi.org/10.1007/s10493-011-9453-5

Demite PR, de Moraes GJ, McMurtry, JA, Denmark, HA, Castilho RC (2020) Phytoseiidae database. www.lea.esalq.usp.br/phytoseiidae. Accessed 03 Jan 1990

dos Santos VV, Tixier MS (2016) Which molecular markers for assessing which taxonomic level? The case study of the mite family Phytoseiidae (Acari: Mesostigmata). Cladistics 33(3):251-267. https ://doi.org/10.1111/cla.12166

dos Santos VV, Tixier MS (2018) Integrative taxonomy approach for analysing evolutionary history of the tribe Euseiini Chant \& McMurtry (Acari: Phytoseiidae). Syst Biodivers 16(3):302-319. https:// doi.org/10.1080/14772000.2017.1401562

Döker I, Kazak C, Karut K (2016) Contributions to the Phytoseiidae (Acari: Mesostigmata) fauna of Turkey: morphological variations, twelve new records, re-description of some species and a revised key to the Turkish species. Syst Appl Acarol 21(4):505-527. https://doi.org/10.11158/saa.21.4.10

Döker İ, Karut K, Karaca MM, Cargnus E, Kazak C (2018) Internal Transcribed Spacer (ITS) sequences of some Kampimodromus (Acari: Phytoseiidae) species: Is Kampimodromus ragusai a valid species or a synonym of Kampimodromus aberrans? Syst Appl Acarol 23(11):2237-2244. https://doi. org/10.11158/saa.23.11.15

Faraji F, Çobanoğlu S, Çakmak I (2011) A checklist and a key for the Phytoseiidae species of Turkey with two new species records (Acari: Mesostigmata). Int J Acarol 37(sup1):221-243. https://doi. org/10.1080/01647954.2011.558851

Hall TA (1999) BioEdit: A user-friendly biological sequence alignment editor and analysis program for windows 95/98/NT. Nucleic Acids Symp Ser 41:95-98

Hebert PD, Cywinska A, Ball SL, Dewaard JR (2003) Biological identifications through DNA barcodes. Proc R Soc Lond B 270(1512):313-321. https://doi.org/10.1098/rspb.2002.2218

Jeyaprakash A, Hoy MA (2002) Mitochondrial 12S rRNA sequences used to design a molecular ladder assay to identify six commercially available phytoseiids (Acari: Phytoseiidae). Biol Control 25(2):136-142. https://doi.org/10.1016/S1049-9644(02)00056-7

Jeyaprakash A, Hoy MA (2010) A DNA extraction procedure that allows mite specimens to be slide mounted: phytoseiid species evaluated as a model. Exp Appl Acarol 52:131-140. https://doi. org/10.1007/s10493-010-9357-9

Kanouh M, Tixier MS, Guichou S, Cheval B, Kreiter S (2010a) Two synonymy cases within the genus Neoseiulella (Acari: Phytoseiidae): is the molecular evidence so evident? Biol J Linn Soc 101(2):323-344. https://doi.org/10.1111/j.1095-8312.2010.01516.x

Kanouh M, Tixier MS, Okassa M, Kreiter S (2010b) Phylogenetic and biogeographic analysis of the genus Phytoseiulus (Acari: Phytoseiidae). Zool Scr 39(5):450-461. https://doi.org/10.111 1/j.1463-6409.2010.00439.x

Katoh K, Rozewicki J, Yamada KD (2019) MAFFT online service: multiple sequence alignment, interactive sequence choice and visualization. Brief Bioinform 20(4):1160-1166. https://doi.org/10.1093/ $\mathrm{bib} / \mathrm{bbx} 108$

Kumar S, Stecher G, Tamura K (2016) MEGA7: molecular evolutionary genetics analysis version 7.0 for bigger datasets. Mol Biol Evol 33(7):1870-1874. https://doi.org/10.1093/molbev/msw054

Lindquist EE, Evans GO (1965) Taxonomic concepts in the Ascidae, with a modified setal nomenclature for the idiosoma of the Gamasina (Acarina: Mesostigmata). Memoirs Ent Soc Can 97(S47):5-66

McMurtry JA, de Moraes GJ, Sourassou NF (2013) Revision of the lifestyles of phytoseiid mites (Acari: Phytoseiidae) and implications for biological control strategies. Syst Appl Acarol 18(4):297-320. https://doi.org/10.11158/saa.18.4.1

McMurtry JA, Sourassou NF, Demite PR (2015) The Phytoseiidae (Acari: Mesostigmata) as biological control agents. In: Carrillo D, et al. (eds) Prospects for biological control of plant feeding mites and other harmful organisms. Springer, Cham, pp 133-149

Miedema E (1987) Survey of phytoseiid mites (Acari: Phytoseiidae) in orchards and surrounding vegetation of northwestern Europe, especially in the Netherlands. Keys, descriptions and figures. Neth $\mathbf{J}$ Plant Pathol 93(2):1-63

Navajas M, Cotton D, Kreiter S, Gutierrez J (1992) Molecular approach in spider mites (Acari: Tetranychidae): preliminary data on ribosomal DNA sequences. Exp Appl Acarol 15:211-218

Navajas M, Gutierrez J, Bonato O, Bolland HR, Mapangoudivassa S (1994) Intraspecific diversity of the cassava green mite Mononycellus progresivus (Acari, Tetranychidae) using comparisons of mitochondrial and nuclear ribosomal DNA-sequences and cross-breeding. Exp Appl Acarol 18:351-360 
Navajas M, Lagnel J, Fauvel G, de Moraes G (1999) Sequence variation of ribosomal internal transcribed spacers (ITS) in commercially important Phytoseiidae mites. Exp Appl Acarol 23(11):851-859

Navajas M, Fenton B (2000) The application of molecular markers in the study of diversity in acarology: a review. Exp Appl Acarol 24(10-11):751-774

Navajas M, Boursot P (2003) Nuclear ribosomal DNA monophyly versus mitochondrial DNA polyphyly in two closely related mite species: the infuence of life history and molecular drive. Proc R Soc Lond B 270(suppl_1):S124-S127. https://doi.org/10.1098/rsbl.2003.0034

Okassa M, Tixier MS, Kreiter S (2010) Morphological and molecular diagnostics of Phytoseiulus persimilis and Phytoseiulus macropilis (Acari: Phytoseiidae). Exp Appl Acarol 52(3):291-303. https:// doi.org/10.1007/s10493-010-9364-x

Okassa M, Kreiter S, Tixier MS (2012) Obtaining molecular data for all life stages of Typhlodromus (Typhlodromus) exhilaratus (Mesostigmata: Phytoseiidae): consequences for species identification. Exp Appl Acarol 57(2):105-116. https://doi.org/10.1007/s10493-012-9548-7

Ros VI, Breeuwer JAJ (2007) Spider mite (Acari: Tetranychidae) mitochondrial COI phylogeny reviewed: host plant relationships, phylogeography, reproductive parasites and barcoding. Exp Appl Acarol 42(4):239-262. https://doi.org/10.1007/s10493-007-9092-z

Rosen D (1986) The role of taxonomy in effective biological control programs. Agr Ecosyst Environ 15(2-3):121-129

Rowell HJ, Chant DA, Hansell RIC (1978) The determination of setal homologies and setal patterns on the dorsal shield in the family Phytoseiidae (Acarina: Mesostigmata). Can Entomol 110(8):859-876

Skoracka A, Magalhaes S, Rector BG, Kuczyński L (2015) Cryptic speciation in the Acari: a function of species lifestyles or our ability to separate species? Exp Appl Acarol 67(2):165-182. https://doi. org/10.1007/s10493-015-9954-8

Tamura K (1992) Estimation of the number of nucleotide substitutions when there are strong transitiontransversion and G+ C-content biases. Mol Biol Evol 9(4):678-687

Tixier MS, Kreiter S, Barbar Z, Ragusa S, Cheval B (2006) Status of two cryptic species, Typhlodromus exhilaratus Ragusa and Typhlodromus phialatus Athias-Henriot (Acari: Phytoseiidae): consequences for taxonomy. Zool Scr 35(2):115-122. https://doi.org/10.1111/j.1463-6409.2006.00222.x

Tixier MS, Guichou S, Kreiter S (2010a) Assessment of the usefulness of eight DNA fragments for phylogenetic studies within the family Phytoseiidae. In: Sabelis M, Bruin J (eds) Trends in acarology. Springer, Dordrecht, pp 41-47

Tixier MS, Okassa M, Liguori M, Poinso A, Salerno B, Kreiter S (2010b) Voucher specimens for DNA sequences of Phytoseiid mites (Acari: Mesostigmata). Acarologia 50(4):487-494. https://doi. org/10.1051/acarologia/20101984

Tixier MS, Hernandes FA, Guichou S, Kreiter S (2011) The puzzle of DNA sequences of Phytoseiidae (Acari: Mesostigmata) in the public GenBank database. Invertebr Syst 25(5):389-406. https://doi. org/10.1071/IS11013

Tixier MS (2012) Statistical approaches to assess intraspecific variations of morphological continuous characters: the case study of the family Phytoseiidae (Acari: Mesostigmata). Cladistics 28(5):489502. https://doi.org/10.1111/j.1096-0031.2012.00394.x

Tixier MS (2013) Statistical approaches to assess interspecific differences for morphological continuous characters: the case study of the family Phytoseiidae (Acari: Mesostigmata). Zool Scr 42(3):327334. https://doi.org/10.1111/zsc. 1200

Tixier MS, dos Santos VV, Douin M, Duso C, Kreiter S (2017) Great molecular variation within the species Phytoseius finitimus (Acari: Phytoseiidae): implications for diagnosis decision within the mite family Phytoseiidae. Acarologia 57(3):493-515. https://doi.org/10.1051/acarologia/20174168

Tixier MS (2018) Predatory mites (Acari: Phytoseiidae) in agro-ecosystems and conservation biological control: a review and explorative approach for forecasting plant-predatory mite interactions and mite dispersal. Front Ecol Evol 6:192. https://doi.org/10.3389/fevo.2018.00192

Tixier MS, Dennj P, Douin M, Kreiter S, Haralabos T (2019) Mites of the genus Typhlodromus (Acari: Phytoseiidae) from Southern France: combined morphological and molecular approaches for species identification. Zootaxa. https://doi.org/10.11646/zootaxa.4604.2.2

Tsolakis H, Tixier MS, Kreiter S, Ragusa S (2012) The concept of genus within the family Phytoseiidae (Acari: Parasitiformes): historical review and phylogenetic analyses of the genus Neoseiulus Hughes. Zool J Linnean Soc 165(2):253-273. https://doi.org/10.1111/j.1096-3642.2011.00809.x

Tuovinen T (1993) Identification and occurrence of phytoseiid mites (Gamasina: Phytoseiidae) in Finnish apple plantations and their surroundings. Entomol Fennica 4(2):95-114

van Lenteren JC (2012) The state of commercial augmentative biological control: plenty of natural enemies, but a frustrating lack of uptake. Biocontrol 57(1):1-20. https://doi.org/10.1007/s1052 6-011-9395-1 
Zhang ZQ (2003) Mites of greenhouses: identification, biology and control. CABI Publishing, Wallington $\mathrm{UK}, \mathrm{p} 244$

Publisher's Note Springer Nature remains neutral with regard to jurisdictional claims in published maps and institutional affiliations. 